\title{
The first known chamopsiid lizard (Squamata) from the Upper Cretaceous of Europe (Csehbánya Formation; Hungary, Bakony Mts)
}

\author{
László Makádi ${ }^{\mathrm{a}, \mathrm{b},{ }^{*}}$ \\ ${ }^{a}$ Department of Paleontology and Geology, Hungarian Natural History Museum, Budapest, \\ Hungary \\ ${ }^{\mathrm{b}}$ Department of Paleontology, Eötvös University, Budapest, Hungary \\ *Corresponding author, email address: iharkutia@yahoo.com
}

\begin{abstract}
The Upper Cretaceous (Santonian) Iharkút terrestrial vertebrate locality, in Hungary, has yielded several lacertilian taxa since its discovery in 2000. One of these is represented by a left mandible fragment and two dentary fragments. The characters observed on these remains support assignment to the family Chamopsiidae (Scincomorpha). Moreover, the remains belong to a new genus and species, Pelsochamops infrequens n. g. n. sp. Pelsochamops is the first known occurrence of chamopsiids outside North America and adds another scincomorphan lizard to the Iharkút fauna. It represents an additional evidence for dispersal routes between North America and Europe.
\end{abstract}

Keywords: Squamata; Chamopsiidae; Upper Cretaceous; Csehbánya Formation; Europe

\section{Résumé}

Formázott: portugál (brazíliai)

gisement de vertébrés terrestres du Crétacé supérieur (Santonien) d'Iharkút a fourni plusieurs taxons de lacertiliens depuis sa découverte en 2000. L'un d'eux est représenté par un fragment de mandibule gauche et deux fragments de dentaires. Les caractères observés sur ces restes soutiennent l'hypothèse d'une attribution à la famille des Chamopsiidae, et même leur appartenance à un nouveau genre et espèce, Pelsochamops infrequens n. g. n. sp.

Pelsochamops est le premier cas connu de chamopsiidé hors d'Amérique du Nord et représente un scincomorphe supplémentaire dans la faune d'Iharkút; c'est aussi une nouvelle preuve de voies de dispersion entre l'Amérique du Nord et l'Europe.

Mots clés: Squamata; Chamopsiidae; Crétacé supérieur; Formation Csehbánya, Europe 


\section{Introduction}

Late Cretaceous terrestrial lizards have been found in various European localities since the

Formázott: francia (franciaországi)

$19^{\text {th }}$ century, the most important remains come from France (Gheerbrant et al., 1997;

Buffetaut et al., 1996; Buffetaut et al., 1997; Buffetaut et al., 1999; Tabuce et al., 2004;

Buffetaut, 2005; Vullo and Néraudeau, 2008; Vullo et al., 2011), Romania (Grigorescu et al., 1999; Codrea et al., 2002; Venczel and Csiki, 2003; Folie and Codrea, 2005; Grigorescu, 2005; Csiki et al., 2008; Codrea et al., 2010a, 2010b; Grigorescu, 2010; Vasile and Csiki, 2010; Weishampel et al., 2010; Vasile and Csiki, 2011; Codrea et al., 2012; Jipa, 2012) and Spain (Rage, 1999; López-Martínez et al., 2000; Company, 2004; Blain et al., 2010; Narváez and Ortega, 2010; Houssaye et al., 2013).

The Iharkút Late Cretaceous (Santonian) terrestrial vertebrate locality, situated in the Bakony Mts, western Hungary (Fig. 1), was discovered in 2000. Since that time, it has yielded remains of lepisosteid and pycnodontiform fishes (Ösi et al., 2012b), albanerpetontid and anuran amphibians (Szentesi and Venczel, 2010, 2012; Szentesi et al., 2013), bothremydid turtles (Rabi et al., 2012), the first known freshwater mosasaur Pannoniasaurus (Makádi et al., 2012), alligatoroid, ziphosuchian and heterodont eusuchian crocodiles (Ösi et al., 2007; Ösi et al., 2012b), azhdarchid pterosaurs (Ösi et al., 2005), a rhabdodontid ornithopod (Ösi et al., 2012a), the ceratopsian dinosaur Ajkaceratops (Ösi et al., 2010b), the basal nodosaurid ankylosaur Hungarosaurus (Ösi, 2005; Ösi and Makádi, 2009), theropods (Ősi et al., 2010a), and enantiornithine birds (Dyke and Ösi, 2010) as well as well-preserved remains of lizards (Makádi, 2006, 2007; Ősi et al., 2012b).

Previously four different lizards (excluding Pannoniasaurus) were distinguished in the Iharkút fauna, based on dentaries, maxillae and isolated teeth (Makádi, 2006, 2007; Ősi et al., 2012b). Among these, the most abundant was Bicuspidon aff. hatzegiensis Folie and Codrea, 2005 from the subfamily Polyglyphanodontinae (Makádi, 2006), and even up till now Bicuspidon unambiguously remains the most frequent lizard of the locality. However, a partial lacertilian mandible with borioteiioid affinities was known to be present it the fauna already in 2006 and was mentioned as 'Teiidae indet.' (Makádi, 2007), or as 'Borioteiioidea indet.' (Ösi et al., 2012b) in various publications.

Recent excavations and screenwashing at Iharkút produced new lacertilian finds, including more material of this taxon, namely two new dentary fragments. These new finds, together with the aforementioned mandible allow the description of a previously unknown chamopsiid species in the Iharkút fauna. 


\section{Geographical and geological setting}

The locality is situated in the Bakony Mts, Western Hungary near the villages Németbánya and Bakonyjákó (Fig. 1A), at the place of the former village Iharkút, destroyed by mining. At the fossil site, the open-pit mining of bauxite exposed the bone-yielding Csehbánya Formation in a thickness of up to 50 meters. The Csehbánya Formation is the overburden of both the Nagytárkány Bauxite Formation and Triassic Main Dolomite Formation (Fig. 1B). It is a flood plain and channel deposit built up of variegated clay, siltstone with grey and brown sand, sand and sandstone beds (Haas et al., 1977; Mindszenty et al., 1984; Knauer and Siegl Farkas, 1992; Jocha-Edelényi, 1996; Ösi and Mindszenty, 2009; Ösi et al., 2012b).

The main bone yielding bed at the locality is at the SZ-6 site (Fig. 1C). SZ-6 is an approximately. 2-3 m thick sequence of beds built up of coarse, pebbly sand and organic-rich silt and clay. The bonebed at SZ-6 is a 10 to $50 \mathrm{~cm}$ thick, basal breccia composed of gray sand, siltstone, clay clasts, pebbles, and plant debris (also charcoal) that occasionally contains surprisingly well-preserved bones, but more frequently yields fragmentary ones. The basal breccia is sometimes interrupted by finer sediments that settled out under calmer circumstances (Fig. 1C). The breccia was previously interpreted as a result of crevasse splay deposits (Ösi et al., 2012b). Almost all vertebrate remains have been found in this sediment by either picking out by hand or screenwashing the sediment left behind after looking for larger bones.

A sand-sandstone bed with a thickness of a few centimeters covers the basal breccia, while the former is overlain by a laminated, grayish siltstone of variable thickness ( $30 \mathrm{~cm}$ to $1.5 \mathrm{~m})$. The sequence is closed by a greyish siltstone of several meters (Ösi and Mindszenty, 2009; Ösi et al., 2012b). The cycles sometimes end with paleosoils, moreover, several similar sequences are exposed within the mine. Practically almost any of these sediments might yield rare vertebrate remains, but the basal breccia is the main bone-yielding horizon (Ösi and Mindszenty, 2009; Ösi et al., 2012b).

In the area, the Csehbánya Formation is sometimes covered by the Eocene Iharkút Conglomerate Formation or just by Quaternary deposits (Fig. 1B); in other locations it is covered by the Oligocene-Miocene Csatka Formation (Haas et al., 1977; Mindszenty et al., 1984; Knauer and Siegl Farkas, 1992; Jocha-Edelényi, 1996; Ösi and Mindszenty, 2009). Palynological studies suggested a Santonian age for the Csehbánya Formation (Knauer and 
Siegl Farkas, 1992), and this age was confirmed by recent paleomagnetic data from samples acquired at the SZ-6 site (Ösi et al., 2012b).

\section{Material and methods}

For the present paper a partial left mandible (MTM 2006.106.1.) and two dentary fragments (MTM PAL 2013.24.1. and PAL 2013.25.1.) were available (Figs. 2-4). All of them were yielded by the bonebed of the SZ-6 site (Fig. 1C).

The bones are black of pyrite and organic material (Tuba et al., 2006), and are extremely fragile, but relatively well preserved. The most complete remain, the partial mandible was found during the field works by picking out by hand. The two dentary fragments were found by screenwashing the sediment that was left behind after looking for larger bones by hand.

Screenwashing at Iharkút usually destroys relatively larger microvertebrate remains because the bones at the locality, though sometimes well preserved, are full of cracks and are sometimes held together by the matrix. Thus it is not unlikely that the dentary fragments were originally more complete, just like the partial mandible.

Preparation of MTM 2006.106.1. was conducted in the laboratory of the Dept. of Paleontology, Eötvös University, using stereo-microscope and dentist's tools. Since MTM PAL 2013.24.1. and PAL 2013.25.1. were screenwashed, no preparation was necessary for their study.

The specimens were fixed with super-glue (cyanoacrylate) and/or PVB (polyvinyl-butyral). ESEM photographs of MTM 2006.106.1. were made with a Hitachi 2360N environmental scanning electron microscope at the Department of Plant Anatomy, Eötvös University. Environmental Scanning Electron Microscopy (ESEM) was first chosen to evade the need for coating the specimen in carbon or gold. Later, in order to achieve better resolution, the specimen was coated with carbon and additional SEM photographs of MTM 2006.106.1. were taken using an Amray 1830I scanning electron microscope at the Department of Petrology and Geochemistry, Eötvös University at an accelerating voltage of $20 \mathrm{kV}$. However, the specimen showed significant charging despite the coating, rendering the images to low quality. After taking the photos the specimen was carefully cleaned of most carbon with ethanol.

MTM PAL 2013.24.1. and PAL 2013.25.1. were photographed through a stereo microscope with a Canon EOS 350D DSLR. 
For the anatomical descriptions of the dentition the orientation terminology proposed by Smith and Dodson (2003) was used. This terminology can be briefly explained as follows: the terms 'mesial' and 'distal' designate tooth surfaces and directions facing toward and away from the mandibular symphysis (thus relative to the median saggital plane of the animal, similarly to limb bones, etc.). 'Labial' stands for those surfaces and directions which face the lips or cheeks, while 'lingual' means those which face the tongue. 'Basal' is used for the direction toward crown or tooth bases, 'apical' is for the direction toward crown tips. 'Occlusal' is used for views of the occlusal surfaces.

The specimens are housed in the Hungarian Natural History Museum (MTM), the abbreviation "MTM PAL" stands for the paleontological collection of the museum (previously only "MTM" was used as a prefix of inventory numbers).

\section{Systematic paleontology}

Order: SQUAMATA Oppel, 1811

Infraorder: SCINCOMORPHA Camp, 1923

Unranked Clade: BORIOTEIIOIDEA Nydam, Eaton et Sankey, 2007

Family: CHAMOPSIIDAE Denton et O’Neill, 1995

Genus: Pelsochamops n. g.

Diagnosis. As for type species (see below).

Type species. Pelsochamops infrequens n. sp.

Included species. Pelsochamops infrequens n. sp.

Type locality and horizon. As for type species (see below).

Etymology. Generic name derived from "Pelso", after Pelso Block, the tectonic unit carrying the Bakony Mts (Lacus Pelso originally being the Latin name for nearby Lake Balaton in Roman times) and from "Chamops", the type genus of the family and, though not explained by Marsh (1892), originally from Greek, "khámo" ( $\chi \alpha \alpha \omega)$ meaning down, and "ops" (ڤ̋ $\psi)$, meaning "face, appearance": "down-face".

\section{Pelsochamops infrequens n. sp.}

Figures 2-4

2007 Teiidae indet., Makádi, p. 29.

2012 Borioteiioidea indet., Ösi et al., p. 566. 
Holotype. MTM 2006.106.1. partial left mandible (Figs. 2 and 3) preserving the posterior part of dentary with four teeth, splenial, coronoid and crushed postdentary bones.

Paratype. MTM PAL 2013.24.1. right dentary fragment (Fig. 4A-C).

Referred specimen. MTM PAL 2013.25.1. left dentary fragment (Fig. 4D-F).

Type locality and horizon. Iharkút open-pit bauxite mine, Bakony Hills, western Hungary, Upper Cretaceous (Santonian) Csehbánya Formation (Ösi et al., 2012b).

Etymology. Specific name "infrequens" meaning infrequent in Latin, a referral to the rarity of the species at Iharkút. Diagnosis: Small Late Cretaceous chamopsiid lizard with uniform, symmetrically monocuspid posterior teeth. Differs from all chamopsiids except Haptosphenus in having coronoid fused. Differs from Chamops, Leptochamops, and Tripennaculus in having monocuspid teeth instead of tricuspid. Differs from Socognathus and Meniscognathus in having non recurved teeth, further differs from Socognathus in having symmetrical tooth crown.

Differs from Gerontoseps in having shorter teeth and lower apex on tooth crown, and having large subcircular resorption pits instead of elongated ones. Differs from Stypodontosaurus in having more gracile dentary and shorter teeth and in lacking well-defined crest encircling horseshoe shaped depression lingually on tooth crown. Differs from Haptosphenus in having more gracile dentary, lack of subacrodonty and massive teeth. Differs from Glyptogenys in having more gracile dentary and symmetrical monocuspid posterior teeth, lacking ornamentation. Differs from Harmodontosaurus in having different tooth crown, lacking shoulder-like process formed by medial carina.

\section{Description and comparisons.}

Holotype, MTM 2006.106.1. right mandible (Figs. 2 and 3)

The most complete partial mandible is $8 \mathrm{~mm}$ long, and preserves a part of the dentary, splenial, and coronoid. The rostral part of the dentary is missing, and the caudal part is partially crushed, making other bones, such as surangular, indistinguishable.

The bone is straight in occlusal view (Fig. 2B) and its ventral border is slightly convex in lingual view (Fig. 2A). In labial view the mandible exhibits a row of small foramina (the exits of nervus alveolaris inferior). No ornamentation is visible on the labial surface, similar to Chamops, Meniscognathus (Estes, 1964), or Harmodontosaurus (Nydam, 2002).

In lingual view (though it is covered by the splenial) the rostral part of the preserved portion of the Meckelian groove is narrow, in caudal direction it widens abruptly below the last but one tooth and its posterior part is widely open. The splenial is articulated to the dentary, not fused as in some specimens of Gerontoseps, or Haptosphenus (Estes, 1964, 1983; 
Gao and Fox, 1996). The subdental shelf is relatively wide labio-lingually and the sulcus dentalis appears to be deep, the latter condition being in contrast to that seen in MTM PAL 2013.24.1. and MTM PAL 2013.25.1., thus can be caused by the slight compression of the remain. Since no suture is visible between them, the coronoid seems to be fused to the dentary, similarly to Haptosphenus (Gao and Fox, 1996).

The dentary preserves the last four teeth. An empty tooth place mesially to them is also visible, while mesially to this empty position a small portion of the broken base of the preceding tooth is preserved, just where the anterior portion of the dentary is broken and missing. The most distal tooth appears to be smaller than the preceding ones, similarly to Chamops (Estes, 1964), though its crown has the same size and its base is crushed thus this is uncertain. Considering the shape of the preserved part of the dentary, and the relatively wide spacing of the teeth, the original tooth count might have been not much higher than 10-15. The tooth attachment is an advanced form of pleurodonty termed 'subpleurodont' in teiioids and borioteiiods, with cementum deposition at the tooth bases, characteristic for the aforementioned groups (Estes et al., 1988; Nydam et al., 2007). The second preserved tooth has a large, subcircular resorption pit-like hole at its base similar to MTM PAL 2013.24.1., however since its edges seem to be broken, its original size is not certain.

Though the most mesial preserved tooth is slightly more slender than the next ones, the preserved part of the dentition is homodont. The cylindrical, relatively widely spaced straight teeth are massively built, robust, with a mid-shaft swelling causing a barrel-shaped look, typical for chamopsiids (Nydam et al., 2010). They project above the labial parapet of the dentary with approximately one third of their height.

The tooth crowns (Fig. 3) are not transversely oriented in contrast to some members of Polyglyphanodontinae (Estes, 1983; Nydam, 1999; Nydam and Cifelli, 2002; Folie and Codrea, 2005; Nydam and Cifelli, 2005) but similar to chamopsiids (Nydam et al., 2010). Though the apices are worn, they show a characteristic morphology, slightly resembling the mesial teeth of Prototeius stageri Denton et O’Neill, 1995 (Denton and O'Neill, 1995), or the teeth mentioned for Chamops cf. segnis specimen OMNH 33852 (Nydam and Voci, 2007: p.214-215 and Fig. 3C). The crowns are basically monocuspid as opposed to e.g. Leptochamops (Estes, 1983), but have mesial and distal accessory ridges, forming shoulders on the crown, similarly to those noted for chamopsiids (Nydam et al., 2010). These ridges, or carinae extend in basal-lingual direction, become very blunt and hardly visible as they meet on the lingual side of the crown, and encompass the apex similarly to a cingulum. 
The crowns bear distinct striation on both their lingual and labial sides similar to the Chamopsiinae of Denton and O’Neill (1995). In occlusal view, enamel and dentine are well distinguishable as the result of wear.

MTM PAL 2013.24.1. right dentary fragment (Fig. 4A-C)

The preserved part is only $1.3 \mathrm{~mm}$ long bearing two complete teeth and an empty tooth place mesially. In labial view (Fig. 4C) the bone exhibits two mental foramina. In lingual view (Fig. 4A), the upper edge of the open Meckelian canal starts to rise just under the last (the second preserved) tooth, indicating that the fragment might be from the posterior part of the dentary, when compared to MTM 2006.106.1.

The preserved teeth project with one third of their height beyond the labial parapet of the dentary. At the base of the mesial preserved tooth, a large subcircular resorption pit is visible, as in most borioteiioids (Nydam et al., 2007), in contrast to Gerontoseps (Gao and Fox, 1996), however at the base of the next tooth the pit is small.

The morphology of the teeth is identical to that seen in MTM 2006.106.1., but in MTM PAL 2013.24.1. the apices of the teeth are not worn (though the second preserved tooth is slightly damaged). The intact first preserved tooth reveals that the mesial and distal accessory ridges are more pronounced than in MTM 2006.106.1. due to the lack of wear or abrasion., however, they are not so prominent as in Chamops (Nydam and Voci, 2007: Fig 3E). These carinae turn abruptly in apical direction when they reach the labial side of the apex, and meet forming a sharp labial corner. This acute point is slightly higher than the apex, in contrast to e.g. Gerontoseps (Gao and Fox, 1996). The morphology described above gives the crown a weakly tricuspid outline in labial and lingual view, but it is obvious that the mesial and distal shoulders formed by the carinae are not cusps, neither regarding their morphology, nor probably their function, this is well visible on the holotype (Fig. 3). The outline of the tooth crown of Pelsochamops in labial and lingual view is not unlike that of Socognathus, but this structure is symmetrical on the Iharkút specimens in contrast to the latter (Nydam et al., 2010). The apex and the pointed labial corner formed by the encompassing carinae are linked together by a short transverse ridge. The apex is finely striated on both its lingual and labial sides.

\section{MTM PAL 2013.24.1. left dentary fragment (Fig. 4D-F)}

This dentary fragment is $2.5 \mathrm{~mm}$ long and bears two preserved teeth distally and the base of a broken one mesially. The shape of the Meckelian canal assumes that it is from the same region of the dentary as MTM PAL 2013.24.1., thus in lingual view it looks like the mirrored counterpart of the latter. However, it is twice larger, and is more poorly preserved, with the 
crowns of the teeth badly worn, abraded. Otherwise, it shows the same morphology as MTM 2006.106.1. or MTM PAL 2013.24.1.

\section{Discussion}

The wide subdental shelf, the caudally wide Meckelian groove, and the cylindrical teeth lead to refer the mandible to the Scincomorpha. The 'subpleurodont' dentition with cementum deposition at the tooth bases, and the large subcircular resorption pits were traditionally interpreted as 'teiid' synapomorphies and were useful characters for the identification of fossil members of Teiidae (sensu Estes et al., 1988) (Estes, 1983; Nydam and Cifelli, 2002). However, since Nydam et al. (2007) have erected the taxon Borioteiioidea for a part of the previous Teiioidea (sensu Estes et al., 1988), the aforementioned characters are synapomorphies for the Teiioidea-Borioteiioidea assemblage.

The first studies of MTM 2006.106.1. already revealed that it might be related to the 'Chamopsiinae' of Denton and O’Neill (1995), especially Chamops, Leptochamops, and Meniscognathus (Denton and O'Neill, 1995). Though MTM 2006.106.1. does not exhibit much of the diagnostic characters of Chamopsiinae (sensu Denton and O'Neill, 1995), its tooth morphology is similar to that of Chamops. Later, Nydam et al. (2010) re-ranked Chamopsiinae as Chamopsiidae, and included Chamops, Leptochamops, and Meniscognathus, as well as several other taxa in the clade, but excluded Prototeius. They diagnosed Chamopsiidae on the basis of the dentary and dentition, helping the assignment of MTM 2006.106.1. and the dentary fragments to this group.

The barrel-shaped teeth, having crowns with a conical apex and bordering mesial and distal accessory ridges, the relative wide spacing of teeth, as well as the lack of transversal elongation of tooth crowns are all synapomorphies of Chamopsiidae (Nydam et al., 2010). Some diagnostic characters, such as the long mandibular symphysis are not observable due to the lack of more complete material of Pelsochamops, however the aforementioned characters make it unequivocal that it belongs to Chamopsiidae.

Chamopsiidae is composed of the following genera, according to Nydam et al. (2010): Chamops, Gerontoseps, Glyptogenys, Harmodontosaurus, Haptosphenus, Leptochamops, Meniscognathus, Socognathus, Stypodontosaurus and Trippenaculus.

Pelsochamops differs from all chamopsiids except Haptosphenus in apparently having its coronoid fused to the dentary. 
It can be easily distinguished also from Chamops in not having true tricuspid teeth posteriorly. Though the last tooth in MTM 2006.106.1 appears diminished in size compared to the preceding ones similarly to Chamops, its crown has the same size as the other teeth and its base is crushed. Thus it is uncertain if Pelsochamops had smaller teeth distally as Chamops (Estes, 1964), or had teeth of equal size all along the distal part of the tooth row.

Leptochamops has even more tricuspid teeth than Chamops, moreover the teeth in $L$. denticulatus are strongly recurved, unlike Pelsochamops (Estes, 1983; Gao and Fox, 1996).

Similarly, Tripennaculus possesses strongly tricuspid tooth crowns with the accessory cusps being nearly as tall as the main one, and also exhibits strong crenulations on the main cusp, unlike the fine striae observed in Pelsochamops (Nydam and Voci, 2007).

Pelsochamops also differs from Socognathus, which has a labial dentary parapet only one third of tooth height as opposed to two thirds, and has a strong mesial and a weaker distal ridge on the tooth crown, instead of equally developed ridges. Moreover, its teeth are set at an oblique angle to axis of dentary, which is not the case in Pelsochamops (Gao and Fox, 1996; Nydam et al., 2010).

The teeth of Meniscognathus are labiolingually compressed and medially concave, the posterior teeth are weakly tricuspid with the distal accessory cusp less developed that the mesial one. In M. molybrochoros the tricuspid posterior teeth are also strongly recurved (Estes, 1964; Gao and Fox, 1996; Nydam and Voci, 2007). This morphology is again different from that of Pelsochamops.

Gerontoseps has its splenial partially fused in some individuals, which does not seem to happen in the case of Pelsochamops. On the tooth crowns of Gerontoseps mesial and distal ridges are more prominent, and teeth have elongated replacement pits positioned posteromedially as opposed to medially situated subcircular pits observed in Pelsochamops. Moreover, no striations on the tooth crowns are mentioned in Gerontoseps (Gao and Fox, 1996).

Stypodontosaurus seems to have a more robust dentary than Pelsochamops, and its tooth crowns are different, Pelsochamops has shorter teeth and it lacks the crest encircling a horseshoe shaped depression lingually on tooth crown that was described in Stypodontosaurus (Gao and Fox, 1996).

Pelsochamops differs from both Haptosphenus and Glyptogenys in having a more gracile dentary (Gao and Fox, 1996). Besides, Haptosphenus has its dentary, splenial, coronoid and surangular fused, its dentary bears massive teeth, the sulcus dentalis is lost, and the labial parapet of the dentary is reduced resulting in a 'subacrodont tooth attachment' (Estes, 1964, 
1983; Gao and Fox, 1996). These features give a characteristic appearence to Haptosphenus, differing markedly from Pelsochamops. The dentary of Glyptogenys similarly differs to a great extent from that of Pelsochamops, in being heavily ornamented in adult specimens, in having its tooth crowns recurved, and bearing bicuspid distal teeth (with a smaller mesial cusp) (Gao and Fox, 1996).

Finally, Harmodontosaurus has different tooth crowns with mesial and distal carinae, the more robust mesial one forming a "shoulder-like process" and a more acute linguodistally directed apex with no medial striae (Nydam, 2002).

It is worth to mention that the tooth morphology exhibited by the paratype of Pelsochamops is not unlike that was described and figured for the probable scincomorphan Bothriagenys mysterion Nydam, 2002 (Nydam, 2002: p.649, Fig. 5). Bothriagenys also seems to have homodont dentition, its preserved most distal two teeth are conical, with the apex being medially striate. The apex is bordered by a mesial and a distal carina that wrap around the crown just like in Pelsochamops, and other chamopsiids. As evidenced by Nydam (2002: Fig. 5), Bothriagenys has the apex and the labial acute tip (which is formed by the meeting mesial and distal carinae) linked together by a transverse ridge, similarly to Pelsochamops, a feature undocumented in other chamopsiids. Otherwise, Bothriagenys differs from Pelsochamops and other members of Chamopsiidae in having a narrow slit-like Meckelian canal, tall and relatively slender teeth lacking the characteristic barrel-shape.

Based on their morphology, MTM 2006.106.1., MTM PAL 2013.24.1. and MTM PAL 2013.25.1. can be assigned to a new genus and species of Chamopsiidae as Pelsochamops infrequens n. g. n. sp. Relationships within the family have not been investigated due to the lack of material (Nydam et al., 2010), and the present paper also leaves these studies pending. Pelsochamops is the first known member of the family in Europe, as well as outside North America.

The oldest known chamopsiid is Harmodontosaurus from the Albian-Cenomanian Mussentuchit Member of the Cedar Mountain Formation (Nydam, 2002), the same unit that yielded Bicuspidon numerosus Nydam et Cifelli, 2002 (Nydam and Cifelli, 2002). Other members of the family occur throughout the Late Cretaceous west of the Western Interior Seaway (Estes 1964, 1983; Gao and Fox, 1996; Nydam et al., 2010). The occurrences of Bicuspidon (Makádi, 2006) and Pelsochamops at Iharkút support paleobiogeographic connections between North America and Europe before the Santonian, as suggested by other authors (Vullo and Néraudeau, 2008), morover these dispersal routes must have also crossed the Western Interior Seaway to let chamopsiids like Pelsochamops (and members of 
Polyglyphanodontinae such as Bicuspidon) disperse to landmasses in the European Archipelago.

\section{Conclusions}

The first known chamopsiid lizard from Europe is described as belonging to a new genus and species. This new species, Pelsochamops infrequens extends the geographic distribution of the family outside North America into the Late Cretaceous of the European Archipelago. Besides adding another species of scincomorphan lizard to the Iharkút fauna, it supports dispersal routes linking the western shores of the Western Interior Seaway in North America to islands in the European area of the Tethys.

\section{Acknowledgements}

The author wishes to thank Randall Nydam and Sebastián Apesteguía for helpful discussions. Jean-Claude Rage and Didier Néraudeau are gratefully acknowledged for critically reading the manuscript and making useful suggestions that greatly improved the work. A. Ösi and the other members of the Iharkút Research Group, the staffs of the Dept. of Paleontology, Eötvös University and of the Dept. of Geology and Paleontology, Hungarian Natural History Museum are acknowledged for their help provided. The help of Péter Pekker and Károly Bóka in taking SEM photos, and the help of Dorothée Drucker and Márton Rabi in translating to French is gratefully acknowledged. Fieldwork and the work of LM was supported by the OTKA NF-84193, as well as the MTA-ELTE Lendület (Dinosaur Research Group, grant n.: 95102) grants. Previously, research at Iharkút was supported by the OTKA T-39045 and PD73021 grants; the National Geographic Society; the Jurassic Foundation; the MOL Plc. and the Hantken Foundation. Fieldwork was also supported by Bakonyi Bauxitbánya Ltd and Geovol Ltd.

\section{References}

Blain, H.-A., Canudo, J.-I., Cuenca-Bescós, G., López-Martínez, N., 2010. Amphibians and squamate reptiles from the latest Maastrichtian (Upper Cretaceous) of Blasi 2 (Huesca, Spain). Cretaceous Research 31, 433-446. 
Buffetaut, E., 2005. Late Cretaceous Vertebrates from the Saint-Chinian area (Southern France): a review of previous research and an update on recent finds. Acta Palaeontologica Romaniae 5, 39-48.

Buffetaut, E., Costa, G., Le Loeuff, J., Martin, M., Rage, J.-C., Valentin, X., Tong, H.,1996. An Early Campanian vertebrate fauna from the Villeveyrac Basin (Hérault, southern France). Neues Jahrbuch für Geologie und Paläontologie Monatshefte 1996, 1-16.

Buffetaut, E., Le Loeuff, J., Cavin, L., Duffaud, S., Gheerbrant, E., Laurent, Y., Martin, M., Rage, J.-C., Tong, H., Vasse, D., 1997. Late Cretaceous non-marine vertebrates from southern France: a review of recent finds. Geobios 20, 101-108.

Buffetaut, E., Le Loeuff, J., Tong, H., Duffaud, S., Cavin, L., Garcia, G., Ward, D., 1999. Un nouveau gisement de vertébrés du Crétacé supérieur à Cruzy (Hérault, Sud de la France). Comptes Rendus de l'Académie des Sciences, Sciences de la Terre 328, 203-208.

Camp, C., 1923. Classification of the lizards. Bulletin American Museum of Natural History 48, 289-481.

Codrea, V., Barbu, O., Jipa-Murzea, C., 2010a. Upper Cretaceous (Maastrichtian) land vertebrate diversity in Alba District (Romania). Bulletin of the Geological Society of Greece 43, 594-601.

Codrea, V., Smith, T., Dica, P., Folie, A., Garcia, G., Godefroit, P., van Itterbeeck, J., 2002. Dinosaur egg nests, mammals, and other vertebrates from a new Maastrichtian site of the Haţeg Basin (Romania). Comptes Rendus Palevol 1, 173-180.

Formázott: portugál (brazíliai)

Codrea, V., Venczel, M., Solomon, A.I., 2012. Squamate diversity of the Late Cretaceous 'Haţeg Island', Romania - Gondwanan links. $4^{\text {th }}$ International Geologica Belgica Meeting 2012 Abstract Book, p. 154.

Codrea, V., Vremir, M., Jipa, C., Godefroit, P., Csiki, Z., Smith, T., Fărcaş, C., 2010b. More than just Nopcsa's Transylvanian dinosaurs: A look outside the Haţeg Basin. Palaeogeography, Palaeoclimatology, Palaeoecology 293, 391-405.

Company, J.R., 2004. Vertebrados continentales del Cretácico Superior (CampanienseMaastrichtiense) de Valencia. PhD dissertation. Universitat de València, Valencia. pp. $1-410$.

Csiki, Z., Ionescu, A., Grigorescu, D., 2008. The Budurone microvertebrate site from the Maastrichtian of the Haţeg Basin - flora, fauna, taphonomy and paleoenvironment. Acta Palaeontologica Romaniae 6, 49-66. 
Denton, R.K., O’Neil, R.C., 1995. Prototeius stageri, gen. et sp. nov., a new teiid lizard from the Upper Cretaceous Marshalltown Formation of New Jersey, with a preliminary phylogenetic revision of the Teiidae. Journal of Vertebrate Paleontology 15, 235-253.

Dyke, G.J., Ösi, A., 2010. A review of Late Cretaceous fossil birds from Hungary. Geological Journal 45, 434-444.

Estes, R., 1964. Fossil vertebrates from the Late Cretaceous Lance Formation, eastern Wyoming. University of California Publications in Geological Sciences 49, 1-186.

Estes, R., 1983. Sauria terrestria, Amphisbaenia. In: Wellnhofer, P. (Ed.), Encyclopedia of Paleoherpetology. Gustav Fischer Verlag, Stuttgart and New York, pp. 1-249.

Estes, R., de Queiroz, K., Gauthier, J.,1988. Phylogenetic relationships within Squamata. In: Estes, R., Pregill, G. (Eds.), Phylogenetic relationships of the lizard families - Essays commemorating Charles L. Camp. Stanford University Press, Stanford, pp. 119-281.

Folie, A., Codrea, V., 2005. New lissamphibians and squamates from the Maastrichtian of Haţeg Basin, Romania. Acta Palaeontologica Polonica 50, 57-71.

Gao, K., Fox, R.C., 1996. Taxonomy and evolution of Late Cretaceous lizards (Reptilia: Squamata) from western Canada. Bulletin of the Carnegie Museum of Natural History 33, $1-107$.

Gheerbrant E., Abrial, C., Capetta, H., 1997. Nouveaux sites a microvertébrés continentaux du Crétacé terminal des Petites Pyrénées (Haute-Garonne et Ariège, France). Geobios 20, 257-269.

Grigorescu, D., 2005. Rediscovery of a 'forgotten land': the last three decades of research on the dinosaur-bearing deposits from the Haţeg Basin. Acta Palaeontologica Romaniae 5, 191-204.

Grigorescu, D., 2010. The Latest Cretaceous fauna with dinosaurs and mammals from the Haţeg Basin - A historical overview. Palaeogeography, Palaeoclimatology, Palaeoecology 293, 271-282.

Grigorescu, D., Venczel, M., Csiki, Z., Limberea, R.,1999. New latest Cretaceous microvertebrate fossil assemblages from the Haţeg Basin (Romania). Netherlands Journal of Geosciences 78, 301-314.

Haas, J., Jocha-Edelényi, E., Császár, G., 1977. Study of Mesozoic formations of the Transdanubian Central Mountains in Hungary. Annual Report of the Geological Institute of Hungary of the year 1975, 259-272. (in Hungarian)

Houssaye, A., Bardet, N., Narváez, I., Ortega, F., 2013. Squamate finding in “'Lo Hueco" (Late Campanian-Early Maastrichtian, Cuenca Province, Spain): the second non-marine 
pythonomorph lizard. Paläontologische Zeitschrift, available online, DOI

10.1007/s12542-013-0164-6

Jipa, C.-C., 2012. Upper Cretaceous continental vertebrate assemblages from Metaliferi sedimentary area: sytematics, paleoecology and paleobiogeography. PhD dissertation abstract. „Babeş-Bolyai” University, Cluj-Napoca, 1-44.

Jocha-Edelényi, E., 1996. Csehbánya Formation, Ajka Coal Formation, in: Császár, G. (Ed.), Basic Lithostratigraphic Units of Hungary. Cretaceous. Geological Institute of Hungary, Budapest, pp. 61-66. (in Hungarian)

Knauer, J., Siegl Farkas, Á., 1992. Palynostratigraphic position of the Senonian beds overlying the Upper Cretaceous bauxite formations of the Bakony Mts. Annual Report of the Geological Institute of Hungary of the year 1990, 463-471. (in Hungarian)

López-Martínez, N., Canudo, J.I., Ardèvol, L., Pereda Suberbiola, X., Orue-Etxebarria, X., Cuenca-Bescós, G., Ruiz-Omeñaca, J.I., Murelaga, X., Feist, M., 2000. New dinosaur sites correlated with Upper Maastrichtian pelagic deposits in the Spanish Pyrenees: implications for the dinosaur extinction pattern in Europe. Cretaceous Research 22, 41-61.

Makádi, L., 2006. Bicuspidon aff. hatzegiensis (Squamata: Scincomorpha: Teiidae) from the Upper Cretaceous Csehbánya Formation (Hungary, Bakony Mts). Acta Geologica Hungarica 49, 373-385.

Makádi, L., 2007. The study of the squamate fauna of the Upper Cretaceous Csehbánya Formation (Iharkút, Bakony Mts). MSc thesis. Eötvös University Department of Paleontology, Budapest, pp. 1-102. (in Hungarian)

Makádi, L., Caldwell, M.C. Ösi, A., 2012. The First Freshwater Mosasauroid (Upper Cretaceous, Hungary) and a New Clade of Basal Mosasauroids. PLoS ONE 7, e51781. doi:10.1371/journal.pone.0051781

Marsh, O.C., 1892. Notice of new reptiles from the Laramie Formation. American Journal of Science 43, 449-453.

Mindszenty, A., Knauer, J., Szantner, F., 1984. Sedimentological features and the conditions of accumulation of the Iharkút bauxite. Földtani Közlöny 114, 19-48. (in Hungarian)

Narváez, I., Ortega, F., 2010. Análisis preliminar de los restos de Iguanidae indet. del

Cretácico Superior de Lo Hueco (Fuentes, Cuenca). Cidaris 30, 205-209.

Nydam, R.L., 1999: Polyglyphanodontinae (Squamata: Teiidae) from the medial and Late Cretaceous: new taxa from Utah, U.S.A. and Baja California del Norte, Mexico, in 
Gillette, D.D. (Ed.), Vertebrate Paleontology in Utah. Utah Geological Survey

Miscellaneous Publication 99-1. Utah Geological Survey, Salt Lake City, pp. 303-317.

Nydam, R.L., 2002. Lizards of the Mussentuchit Local Fauna (Albian-Cenomanian boundary) and comments on the evolution of the Cretaceous lizard fauna of North America. Journal of Vertebrate Paleontology 22, 645-660.

Nydam, R.L., Caldwell, M.W., Fanti, F., 2010. Borioteiioidean lizard skulls from Kleskun Hill (Wapiti Formation; Upper Campanian), West-Central Alberta, Canada. Journal of Vertebrate Paleontology 30, 1090-1099.

Nydam, R.L., Cifelli, R.L., 2002. A new teiid lizard from the Cedar Mountain Formation

(Albian-Cenomanian boundary) of Utah. Journal of Vertebrate Paleontology 22, 276-285.

Nydam, R.L., Cifelli, R.L., 2005. New data on the dentition of the scincomorphan lizard Polyglyphanodon sternbergi. Acta Palaeontologica Polonica 50, 73-78.

Nydam, R.L., Voci, G.E., 2007. Teiid-like scincomorphan lizards from the Late Cretaceous (Campanian) of southern Utah. Journal of Herpetology 41, 211-219.

Nydam, R.L., Eaton, J.G., Sankey, J., 2007. New taxa of transversely-toothed lizards (Squamata: Scincomorpha) and new information on the evolutionary history of 'teiids' Journal of Paleontology 81, 538-549.

Oppel, M., 1811. Die Ordnungen, Familien und Gattungen der Reptilien als Prodom einer Naturgeschichte derselben. Joseph Lindauer Verlag, München, pp. 1-86.

Ösi, A., 2005. Hungarosaurus tormai, a new ankylosaur (Dinosauria) from the Upper Cretaceous of Hungary. Journal of Vertebrate Paleontology 25, 370-383.

Ösi, A., Apesteguía, S., Kowalewski, M., 2010. Non-avian theropod dinosaurs from the early Late Cretaceous of Central Europe. Cretaceous Research 31, 304-320.

Ösi, A., Butler, R.J., Weishampel, D.B., 2010. A Late Cretaceous ceratopsian dinosaur from Europe with Asian affinities. Nature 465, 466-468.

Ösi, A., Clark, J.M., Weishampel, D.B., 2007. First report on a new eusuchian crocodyliform with multicusped teeth from the Upper Cretaceous (Santonian) of Hungary. Neues Jahrbuch für Geologie und Paläontologie Abhandlungen 243, 169-177.

Ösi, A., Makádi, L., 2009. New remains of Hungarosaurus tormai (Ankylosauria,

Dinosauria) from the Upper Cretaceous of Hungary: skeletal reconstruction and body mass estimation. Paläontologische Zeitschrift 83, 227-245.

Ösi, A., Mindszenty, A., 2009. Iharkút, dinosaur-bearing alluvial complex of the Csehbánya Formation. In: Babinszky, E. (Ed.), Cretaceous sediments of the Transdanubian Range. Hungarian Geological Society, Budapest, pp. 51-63. 
Ösi, A., Prondvai, E., Butler, R.J., Weishampel, D.B., 2012a. Phylogeny, histology and inferred body size evolution in a new rhabdodontid dinosaur from the Late Cretaceous of Hungary. PLoS ONE 7, e44318. doi:10.1371/journal.pone.0044318

Ösi, A., Rabi, M., Makádi, L., Szentesi, Z., Botfalvai, G., Gulyás, P., 2012b. The Late Cretaceous continental vertebrate fauna from Iharkút (Western Hungary): a review. In: Godefroit, P. (Ed.), Bernissart Dinosaurs and Early Cretaceous Terrestrial Ecosystems. Indiana University Press, Bloomington, pp. 532-569.

Ösi, A., Weishampel, D.B., Jianu, C.M., 2005. First evidence of azhdarchid pterosaurs from the Late Cretaceous of Hungary. Acta Palaeontologica Polonica 50, 777-787.

Rabi, M., Tong, H., Botfalvai, G., 2012. A new species of the side-necked turtle Foxemys (Pelomedusoides: Bothremydidae) from the Late Cretaceous of Hungary and the historical biogeography of the Bothremydini. Geological Magazine 149, 662-674.

Rage, J.-C., 1999. Squamates (Reptilia) from the Upper Cretaceous of Laño (Basque Country, Spain). Estudios del Museo de Ciencias Naturales de Alava 14, 121-133.

Smith, J.B., Dodson, P., 2003. A proposal for a standard terminology of anatomical notation and orientation in fossil vertebrate dentitions. Journal of Vertebrate Paleontology 23, $1-12$.

Szentesi, Z., Venczel, M., 2010. An advanced anuran from the Late Cretaceous (Santonian) of Hungary. Neues Jahrbuch für Geologie und Paläontologie Abhandlungen 256, 291-302.

Szentesi, Z., Venczel, M., 2012. A new discoglossid frog from the Upper Cretaceous (Santonian) of Hungary. Cretaceous Research 34, 327-333.

Szentesi, Z., Gardner, J.D., Venczel, M., 2013. Albanerpetontid amphibians from the Late Cretaceous (Santonian) of Iharkút, Hungary, with remarks on regional differences in Late Cretaceous Laurasian amphibian assemblages. Canadian Journal of Earth Sciences 50, 268-281.

Tabuce, R., Vianey-Liaud, M., Garcia, G., 2004. A eutherian mammal in the latest Cretaceous of Vitrolles, southern France. Acta Palaeontologica Polonica 49, 347-356.

Tuba, Gy., Kiss, P., Pósfai, M., Mindszenty, A., 2006 Preliminary data on the diagenesis of Cretaceous dinosaur bones from the Bakony Mts, Hungary. Földtani Közlöny 136, 1-24. (in Hungarian)

Vasile, Ş., Csiki, Z., 2010. Comparative paleoecological analysis of some microvertebrate fossil assemblages from the Haţeg Basin, Romania. Oltenia. Studii şi comunicări. Ştiinţele Naturii 26, 315-322. 
Vasile, S,., Csiki, Z., 2011. New Maastrichtian microvertebrates from the Ruscă Montana basin (Romania). Oltenia. Studii şi comunicări. Ştiinţele Naturii 27, 221-230.

Venczel, M., Csiki, Z., 2003. New frogs from the latest Cretaceous of Haţeg Basin, Romania. Acta Palaeontologica Polonica 48, 609-616.

Vullo, R., Néraudeau, D., 2008. Cenomanian vertebrate assemblages from southwestern France: a new insight into the European mid-Cretaceous continental fauna. Cretaceous Research 29, 930-935.

Vullo, R., Rage, J.-C., Néraudeau, D., 2011. Anuran and squamate remains from the Cenomanian (Late Cretaceous) of Charentes, western France. Journal of Vertebrate Paleontology 31, 279-291.

Weishampel, D.B., Csiki, Z., Benton, M.J., Grigorescu, D., Codrea, V., 2010.

Palaeobiogeographic relationships of the Haţeg biota - Between isolation and innovation. Palaeogeography, Palaeoclimatology, Palaeoecology 293, 419-437. 


\section{Figure legends}

Fig. 1. Geographical and geological setting. Geography (A) and geology of the Iharkút vertebrate locality (B) and the most important SZ-6 site (C) within the mine. Q: Quaternary, ICF: Iharkút Conglomerate Formation, CsF: Csehbánya Formation, NBF: Nagytárkány Bauxite Formation, MDF: Main Dolomite Formation.

Contexte géographique et géologique. Géographie (A) et géologie du gisement de vertébrés d'Iharkút (B) et du plus important site, SZ-6 (C), à l'intérieur de la carrière. Q: Quaternaire, ICF: Formation Conglomérat d'Iharkút, CsF: Formation Csehbánya, NBF: Formation du Bauxite de Nagytárkány, MDF: Formation de la Dolomie Principale.

Fig. 2. Holotype partial left mandible (MTM 2006.106.1.) of Pelsochamops infrequens n. g. n. sp. from Iharkút. A, lingual view; B, occlusal view. ESEM micrographs. Scale bar equals 1 $\mathrm{mm}$.

Holotype, mandibule gauche incomplète (MTM 2006.106.1.) de Pelsochamops infrequens $n$. g. n. sp. d'Iharkút. A, vue linguale; B, vue occlusale. Images MEB. L'échelle est égale à 1 $m m$.

Fig. 3. Tooth crown of the holotype (MTM 2006.106.1.) of Pelsochamops infrequens $\mathrm{n} . \mathrm{g}$. $\mathrm{n}$. sp. from Iharkút in lingual view. ESEM micrograph. Scale bar equals $200 \mu \mathrm{m}$. Couronne dentaire de l'holotype (MTM 2006.106.1.) de Pelsochamops infrequens $n$. g. n. sp. Formázott: portugál (brazíliai) d'Iharkút en vue linguale. Image MEB. L'échelle est égale à 200 um.

Fig. 4. Paratype (MTM PAL 2013.24.1.) and referred material (MTM PAL 2013.25.1.) of Pelsochamops infrequens n. g. n. sp. from Iharkút. Paratype right dentary fragment in A, lingual, B, occlusal, and C, labial views. Left dentary fragment in D, lingual, E, occlusal, and $\mathrm{F}$, labial views. Scale bars equal $1 \mathrm{~mm}$.

Paratype (MTM PAL 2013.24.1.) et matériel de référence(MTM PAL 2013.25.1.) de Pelsochamops infrequens $n$. g. n. sp. d'Iharkút. Paratype, fragment de dentaire droit en vues linguale, A, occlusale, B, et labiale, C. Fragment de dentaire gauche en vues linguale, D, occlusale, E, et labiale, $F$. L'échelle est égale à $1 \mathrm{~mm}$. 